\title{
Elucidating the Regulatory Functions of MlrA Originated from Novosphingobium sp. THN1 in Microcystin-LR Degradation
}

Jieming Li, Ruiping Wang and $\mathrm{Ji} \mathrm{Li}^{*}$

College of Resources and Environmental Sciences, China Agricultural University, Beijing 100193, PR China

\begin{abstract}
Microcystin-LR (MC-LR), produced by harmful cyanobacteria, seriously endangers animals and humans. Biodegradation appears as the major pathway for natural MC-LR attenuation. To elucidate the regulatory function of mIrA gene of Novosphingobium sp. THN1 (i.e., THN1-mIrA gene) in MC-LR biodegradation, this study constructed a recombinant bacterium and succeeded in heterlogously expressing the MIrA of THN1 strain (i.e., THN1-MIrA enzyme). The recombinant MlrA exhibited the activity for smoothly degrading $20 \mu \mathrm{g} \mathrm{mL}^{-1}$ of MC-LR at an average rate of 0.16 $\mu \mathrm{g} \mathrm{mL}-1 \mathrm{~h}^{-1}$ within $80 \mathrm{~h}$. Mass spectrum analysis confirmed that recombinant MlrA hydrolyzed cyclic MC-LR by cleaving the peptide bond between Adda and arginine residue and generated linearized MC-LR as primary intermediate. Such linearization for MC-LR catalyzed by THN1-MIrA enzyme was particularly important during MC-LR biodegradation process, because it opened the highly-stable cyclic structure of MC-LR and caused substantial detoxification. These findings for the first time manifested that $\mathrm{mIrA}$ gene homolog of Novosphingobium genus conserved its original catalytic function as described elsewhere. This study expanded the knowledge on the function of mlrA homologs from various natural habitats, and facilitated the understanding on the fate and biological attenuation mechanisms of MC-LR in Lake Taihu, China, where THN1 strain is indigenous.
\end{abstract}

Keywords: Biodegradation; Linearization; Microcystin-LR; $m l r A$ gene homolog; Novosphingobium sp. THN1

\section{Introduction}

Microcystins (MCs), the most ubiquitous cyanotoxins, are mainly produced and released by harmful cyanobacteria in freshwaters worldwide [1]. As a group of cyclic cyanotoxins, MCs share a general

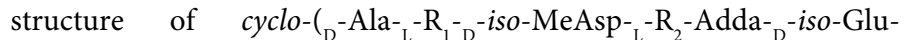
Mdha-), where $\mathrm{R}_{1}$ and $\mathrm{R}_{2}$ are two variable $\mathrm{L}$-amino acids (Figure 1 ), and elicit potent carcinogenic and even lethal effects on aquatic organisms and humans through protein phosphatases (PPs) inhibition [2]. The cyclic structure endows MCs with strong physic-chemical stability and resistance against hydrolysis, oxidation and common proteases $[3,4]$. Since most MC-contaminated freshwaters (i.e., lakes, reservoirs) are the water sources of drinking and agro-irrigation uses for surrounding regions, to remove MCs from freshwaters and to understand removal mechanisms is thus paramount to guarantee ecological and public health.

Biodegradation is recognized as the major mechanism for natural MCs attenuation and can be achieved owing to specific protease $[5,6]$. Among numerous analogs of MCs, microcystin-LR (MC-LR) ${ }_{\mathrm{L}}$-leucine and ${ }_{L}$-arginine at sites $R_{1}$ and $R_{2}$, respectively) is the most toxic and commonly problematic one that has been extensively studied [7]. Bourne et al. [8,9] identified $m l r A$ gene as prime important for MCLR degradation by bacterium Sphingomonas sp. ACM3962 indigenous to Australian freshwater, because the $m l r A$-encoded enzyme initiates biodegradation by hydrolyzing highly-stable cyclic MC-LR at Addaarginine bond into a linearized form. Such linearized intermediate is 160 -fold less toxic and more susceptible to rapid degradation than cyclic parent MC-LR [8-10]. To date, mlrA gene homolog is verified as a unique biomarker of diverse MC-degraders originated from various habitats [6]. Thus, to explore whether $m l r A$ gene homologs of other MC-degraders exert the similar function as ACM-3962 strain is crucial to understand the fate and attenuation mechanism of MC-LR in their respective original habitats.

A novel bacterium named THN1, indigenous to Lake Taihu of
China, has recently been identified as the first MC-degrader affiliated with Novosphingobium genus and able to degrade MC-LR (mg L-1 level) in virtue of its $m l r A$ gene expression [11]. Further study elaborated that divergent expression of $m l r A$ gene greatly affected MC-LR degradation potency of THN1 under various nutrient conditions [12]. Although these findings have suggested the indispensability of $m l r A$ gene in mediating MC-LR degradation by THN1 strain, yet the actual function of $m l r A$ gene harbored in THN1 strain (referred as THN1-mlrA) during MCLR degradation process was not exactly clear. Also, it should be noted that the $m l r A$ gene function of aforementioned MC-LR degraders may not be fully applicable for THN1 strain, because of potential variations in amino acid sequences of and enzyme structures encoded by $\mathrm{mlr} A$ gene homologs of different degraders. Study on preservation and/or evolutionary change of MlrA homologs function is vital to clarify MCLR fate in aquatic habitats. Thus, the regulatory function of THN1-mlr gene in MC-LR degradation deserves experimental validation.

Heterologous expression emerged as a promising way to easily explore the regulatory roles of particular gene. By cloning and expressing THN1-mlrA gene in heterologous host, this study mainly aimed to analyze the degradation products of recombinant mlrA, based on the fragmentation patterns of mass spectrum, to enable an accurate and credible verification on the function of THN1-mlrA gene in MCLR biodegradation process. The results were helpful to comprehend potential fate and biotransformation mechanism of MC-LR in Lake

*Corresponding author: $\mathrm{Ji} \mathrm{Li}$, College of Resources and Environmental Sciences, China Agricultural University, No. 2 Yuanmingyuan West Road, Haidian District, Beijing 100193, PR China, Tel: +861062731130; E-mail: lijm@cau.edu.cn

Received February 28, 2018; Accepted March 07, 2018; Published March 12 , 2018

Citation: Li J, Wang R, Li J (2018) Elucidating the Regulatory Functions of MlrA Originated from Novosphingobium sp. THN1 in Microcystin-LR Degradation. J Environ Anal Toxicol 8: 556. doi: 10.4172/2161-0525.1000556

Copyright: @ $2018 \mathrm{Li} \mathrm{J}$, et al. This is an open-access article distributed under the terms of the Creative Commons Attribution License, which permits unrestricted use, distribution, and reproduction in any medium, provided the original author and source are credited. 
Citation: Li J, Wang R, Li J (2018) Elucidating the Regulatory Functions of MlrA Originated from Novosphingobium sp. THN1 in Microcystin-LR Degradation. J Environ Anal Toxicol 8: 556. doi: 10.4172/2161-0525.1000556

Page 2 of 6

Taihu, and assess the ecological significance of MlrA originated from THN1 (referred as THN1-MlrA) in MC-LR decontamination. Also, the findings provided new insights into the concern that whether THN1MlrA enzyme conserves its original catalytic roles of ring-opening and detoxification for MC-LR, as initially reported by Bourne et al. [9].

\section{Materials and Methods}

\section{Test bacterium and materials}

The wild-type Novosphingobium sp. THN1 strain was grown in Luria-Bertani (LB) broth (tryptone $10 \mathrm{~g}$, yeast extract $5 \mathrm{~g}$ and $\mathrm{NaCl}$ $10 \mathrm{~g}$ per $1 \mathrm{~L}$ at $\mathrm{pH} 7.2$, autoclaved at $121^{\circ} \mathrm{C}$ for $20 \mathrm{~min}$ ) at $30^{\circ} \mathrm{C}$ for $24 \mathrm{~h}$. Bacterial cells were harvested by centrifugation at $3000 \mathrm{r} \mathrm{min}$ ${ }^{1}$ for $5 \mathrm{~min}$, and rinsed twice with $0.01 \mathrm{~mol} \mathrm{~L}^{-1}$ phosphate-buffered saline (PBS) ( $\mathrm{NaCl} 8 \mathrm{~g}, \mathrm{KCl} 0.2 \mathrm{~g}, \mathrm{Na}_{2} \mathrm{HPO}_{4} 1.42 \mathrm{~g}$ and $\mathrm{KH}_{2} \mathrm{PO}_{4} 0.27$ g per $1000 \mathrm{~mL}$ at $\mathrm{pH} 7.4$, autoclaved at $121^{\circ} \mathrm{C}$ for $20 \mathrm{~min}$ ) before resuspended in certain volume of PBS. The host strains and plasmids used in this study are listed in Table 1. MC-LR (95\% purity) was purchased from Express Technology Co., Ltd., China, and stored at $-20^{\circ} \mathrm{C}$. Other chemical regents were analytical grade except as specified by kit or by instruction.

\section{Amplification of THN1-mlrA gene}

To amplify full length of THN1-mlrA gene by polymerase chain reaction (PCR), the primers were designed according to the sequence deposited in Genbank (accession No.: HQ664118), with the forward and reverse primer carrying BamH I and Xho I restriction site, respectively (Table 1). PCR was conducted on a Veriti 96 Well Thermal Cycler (Applied Biosystems, Foster City, CA, USA) in triplicate to ensure reproducibility. Reaction mixture contained $2 \mu \mathrm{L}$ of Takara $10 \times$ Extaq buffer, $1.6 \mu \mathrm{L}$ of deoxynucleoside triphosphates, $0.5 \mu \mathrm{M}$ of each primer, $0.1 \mu \mathrm{L}$ of Takara Extaq DNA polymerase, and $1 \mu \mathrm{L}$ of DNA extracted from THN1 strain as template, with supplement of sterile $\mathrm{ddH}_{2} \mathrm{O}$ up to a total volume of $20 \mu \mathrm{L}$. Amplification included an initial denaturation at $94^{\circ} \mathrm{C}$ for $5 \mathrm{~min}$, followed by 40 cycles of denaturation at $94^{\circ} \mathrm{C}$ for 30 s, primer annealing at $60^{\circ} \mathrm{C}$ for $30 \mathrm{~s}$ and primer extension at $72^{\circ} \mathrm{C}$ for $65 \mathrm{~s}$. A final extension step was performed at $72^{\circ} \mathrm{C}$ for 7 min prior to cooling at $4^{\circ} \mathrm{C}$ [13]. Sterile $\mathrm{ddH} 2 \mathrm{O}$ was used as the template for parallel negative control. The PCR product with expected size was visualized by electrophoresis on $0.7 \%(w / v)$ agarose gel stained with SYBR Green I (Invitrogen Co., Carlsbad, CA, USA).

\section{Construction of recombinant bacterium}

The target gene band with appropriate size was excised from electrophoresis gel and purified by AxyPrep ${ }^{\mathrm{TM}}$ DNA Gel Extraction Kit following manufacturer's instruction (Axygen Biotech. Co. Ltd.,
Carlsbad, CA, USA), and then ligated with pMD18-T cloning vector. Ligation reaction mixture comprising $1 \mu \mathrm{L}$ of pMD18-T vector, $4 \mu \mathrm{L}$ of insert DNA and $5 \mu \mathrm{L}$ of solution I was incubated at $16^{\circ} \mathrm{C}$ overnight (Takara Biotech. Co. Ltd., Dalian, China). The recombinant plasmid pMD18-T-mlrA was transformed into competent E. coli DH5a using the standard heat-shock protocol [14]. Positive clones carrying target gene were grown on LB agar plate supplemented with ampicillin $(50 \mu \mathrm{g}$ $\left.\mathrm{mL}^{-1}\right)$ and X-Gal $\left(100 \mu \mathrm{g} \mathrm{mL}^{-1}\right)$ for $16 \mathrm{~h}$, selected using blue-white spot screening and verified by sequencing after colony PCR [15].

The plasmid pMD18-T-mlrA was extracted from positive clones using AxyPrep ${ }^{\mathrm{TM}}$ Plasmid Miniprep Kit following manufacturer's instruction (Axygen Biotech. Co. Ltd., Carlsbad, CA, USA), and digested with endonucleases BamH I and Xho I. After visualization by electrophoresis and gel purification, the target gene were sub-cloned into expression vector pET-29a (+), which had been digested with the same endonucleases, by aid of T4 DNA ligase (Takara Biotech. Co. Ltd., Dalian, China). The ligation product was transformed into competent E. coli DH5a. Positive clones were cultured and screened out on LB agar plate supplemented with kanamycin $\left(50 \mu \mathrm{g} \mathrm{mL} \mathrm{m}^{-1}\right)$. After verification by sequencing, recombinant plasmid pET-29a-mlrA was isolated and transformed into competent $E$. coli BL21. The resultant recombinant bacterium was designated as pET-29a-mlrA-BL21. Meanwhile, blank vector $\mathrm{pET}-29 \mathrm{a}(+)$ without any insert was transformed into competent E. coli BL21 to construct a negative control (named pET-29a-BL21) in downstream experiments where required.

\section{Induction of recombinant MlrA expression}

The recombinant bacterium and negative control was independently grown in LB broth containing kanamycin $(50 \mu \mathrm{g} \mathrm{mL}$ $\left.{ }^{1}\right)$ on a shaker at $150 \mathrm{r} \mathrm{min}-1$ and $37^{\circ} \mathrm{C}$. When an optical density at $600 \mathrm{~nm}$ (OD600) of 0.8 reached, the cells were induced with $1 \mathrm{mM}$ of isopropyl- $\beta$-d-thiogalactoside (IPTG) at $25^{\circ} \mathrm{C}$ for overnight. One milliliter of subsample was taken from recombinant culture and negative control culture before and after induction, respectively. The cells in subsample were collected by centrifugation at $8000 \mathrm{r} \mathrm{min}^{-1}$ for $2 \mathrm{~min}$ and re-suspended in $200 \mu \mathrm{L}$ of $1 \times$ sodium dodecyl sulfate (SDS) loading buffer. All suspensions were deactivated by boiling for 3 min and mlrA expression was examined using SDS-polyacrylamide gel electrophoresis (PAGE) on 15\% polyacrylamide gel stained with coomassie brilliant blue [16].

\section{MC-LR degradation by recombinant MlrA}

The remaining recombinant culture after induction was centrifuged at $3000 \mathrm{r} \mathrm{min}^{-1}$ for $5 \mathrm{~min}$ for cell collection. The cells were rinsed thrice with PBS, and re-suspended in PBS with equal volume as the

\begin{tabular}{|c|c|c|}
\hline Strains, plasmids and primers & Relevant characteristics & Source or reference \\
\hline \multicolumn{3}{|l|}{ Strains } \\
\hline Escherichia coli $\mathrm{DH} 5 \alpha$ & Competent cell, Cloning host strain & Beijing Cowin Biotech., China \\
\hline Escherichia coli BL21 (DE3) & Competent cell, Expression host strain & Beijing Cowin Biotech., China \\
\hline \multicolumn{3}{|l|}{ Plasmids } \\
\hline pMD18-T & $A m p^{R}$, TA cloning vector ${ }^{a}$ & Takara Bio. (Japan) \\
\hline pET-29a(+) & $\mathrm{Kan}^{\mathrm{R}}$, Expression vector ${ }^{\mathrm{a}}$ & Laboratory stock \\
\hline Primers & Sequence (5'-3') & \\
\hline $\operatorname{MIrA~F~(BamHI)b}$ & CGCGGATCCATGCGGGAGTTTGTCCGAC & This study \\
\hline MIrA R $(X h o l)^{\mathrm{b}}$ & CCGCTCGAGCGCGTTCGAGCCGGACTTG & This study \\
\hline
\end{tabular}

${ }^{a} \mathrm{Amp} \mathrm{P}^{\mathrm{R}}$ and $\mathrm{Kan}^{\mathrm{R}}$ indicate resistance to ampicillin and kanamycin, respectively; ${ }^{b}$ Underlined sequence was the recognition sites of specific restriction endonuclease shown in the bracket.

Table 1: Host strains, plasmids and PCR-primers used in this study. 
Citation: Li J, Wang R, Li J (2018) Elucidating the Regulatory Functions of MlrA Originated from Novosphingobium sp. THN1 in Microcystin-LR Degradation. J Environ Anal Toxicol 8: 556. doi: 10.4172/2161-0525.1000556

Page 3 of 6

remaining culture to achieve a suspension of induced recombinant. The suspension was treated by ultrasonic processing at output power of $250 \mathrm{~W}$ for $20 \mathrm{~min}$ to lyse the cells, during which every working time of $3 \mathrm{~s}$ was alternated with an interval of $3 \mathrm{~s}$, and centrifuged at 12000 $\mathrm{r} \min ^{-1}$ and $4^{\circ} \mathrm{C}$ for $10 \mathrm{~min}$ to discard the debris. The supernatant was completely retrieved as cell-free crude enzymes (CE) extract of induced recombinant. Meanwhile, the remaining culture of negative control after induction was processed with the same procedures as described above to accomplish a cell-free extract of induced control.

To test MC-LR degradation activity of recombinant MlrA, MCLR (final concentration: $20 \mu \mathrm{g} \mathrm{mL} \mathrm{mL}^{-1}$ ) was spiked into sterile $50 \mathrm{~mL}$ Erlenmeyer flask containing $8 \mathrm{~mL}$ of cell-free CE extract of induced recombinant. The system containing $20 \mu \mathrm{g} \mathrm{mL}^{-1}$ of MC-LR and $8 \mathrm{~mL}$ of cell-free extract of induced control was established in parallel to strictly assess any influence of host strain and blank expression vector on MCLR loss. Each system was capped and incubated at $30^{\circ} \mathrm{C}$ with a shaking rate of $220 \mathrm{r} \mathrm{min}^{-1}$. Triplicate systems were periodically sacrificed for analyzing MC-LR and its degradation products.

\section{Analysis of MC-LR and primary degradation products}

Two milliliter of subsample from each system was centrifuged at $3000 \mathrm{r} \mathrm{min}^{-1}$ for $5 \mathrm{~min}$, and $1 \mathrm{~mL}$ of supernatant was immediately applied to quantify MC-LR by a high performance liquid chromatography (HPLC) (Agilent Technologies 1260 Infinity, USA) fitted with a Bonna-Agela Venusil XBP (L) $\mathrm{C}_{18}$ column $(4.6 \mathrm{~mm} \times 250 \mathrm{~mm}, 5 \mu \mathrm{m})$. The operational conditions were congruent with $(12,17)$, except minor modification. Briefly, a mixture including chromatographic grade methanol and $0.05 \mathrm{M}$ phosphate buffer $(\mathrm{pH} 2.5)(60: 40, v / v)$ acted as the mobile phase at a flow rate of $0.58 \mathrm{~mL} \mathrm{~min}{ }^{-1}$. The injected volume and column temperature was $50 \mu \mathrm{L}$ and $40^{\circ} \mathrm{C}$, respectively. MC-LR was quantified by calibrating the peak area at wavelength of $238 \mathrm{~nm}$ with that of external standard. The HPLC system had a detection limit of $0.1 \mu \mathrm{g} \mathrm{L} \mathrm{L}^{-1}$.

To identify the character of primary degradation products, the products were concentrated using a $\mathrm{C}_{18}$ solid-phase extraction cartridge (Bonna-Agela Technologies Co., Ltd., China) and eluted by methanol. Using a Thermo Q-Exactive high resolution mass spectrometer (Thermo Scientific, Waltham, MA, USA), full-scan mass spectrometry (MS) was operated in positive-mode electrospray ionization (ESI) to analyze the products. Both the precursor ions in samples and internal standards were measured from MS assay. The ESI parameters were specified as: resolution at 70,000, mass range from 900 to 1100 , spray voltage at $3.8 \mathrm{kV}$, S-lens RF level at 50.0, and capillary temperature at $320^{\circ} \mathrm{C}$.

\section{Results}

\section{Construction of $m l r A$-carrying recombinant bacterium}

Recombinant plasmids pMD18-T-mlrA and pET-29a-mlrA were propagated successively in cloning host. Sequencing results verified that THN1-mlrA gene was inserted correctly into proper vector, and pET-29a-mlrA was transformed into expression host to obtain the recombinant bacterium. The inserted mlrA originated from THN1 had an open reading frame of 1008 nucleotides (excluding termination codon) that encodes putative 336 amino acid residues.

\section{MlrA production from recombinant bacterium}

SDS-PAGE assay confirmed that MlrA protein was obviously expressed in recombinant cells after IPTG-induction. By contrast, corresponding protein was absent in the lanes for recombinant cells before induction and negative control (pET-29a-BL21) before and after induction (data not shown). These demonstrated that recombinant MlrA, originated from THN1 strain, can be successfully expressed in heterologous host after IPTG-induction.

\section{Characterization of MC-LR and its primary degradation products}

To testify the degradation activity of recombinant MlrA, cell-free CE extract of pET-29a-mlrA-BL21 was prepared to degrade MC-LR. HPLC profile displayed that MC-LR peak at retention time between 16.1 and $16.3 \mathrm{~min}$ decreased in its area and height as time elapsed. Correspondingly, a new peak at retention time of around $10.0 \mathrm{~min}$ emerged and increased in both peak area and height, accompanied with decreasing MC-LR peak (Figures 2A-2C). This implied that the MlrA produced from recombinant cells possessed MC-LR-degrading activity, and the new peak could be deemed as the intermediate products catalyzed by MlrA enzyme. In contrast, initial MC-LR concentration kept roughly constant in the cell-free extract of negative control (Figure 3), confirming that neither heterologous host nor blank expression vector had MC-LR degradation potency, and that any MC-LR loss could be due to biodegradation by expressed MlrA from recombinant cells. As shown in Figure 3, MC-LR was readily and progressively degraded at an average rate of $0.16 \mu \mathrm{mL}^{-1} \mathrm{~h}^{-1}$ in $\mathrm{CE}$ extract of recombinant cells throughout the test period, and almost $70 \%$ of initially-spiked amount was removed until $80 \mathrm{~h}$.

MS spectrum profile exhibited two major ion peaks at mass-tocharge ratio $(\mathrm{m} / \mathrm{z}) 995.6$ and 1013.6, respectively (Figure 4). The peak at $\mathrm{m} / \mathrm{z} 995.6$ represented the protonated molecular ion of parent MCLR $\left((\text { Mass }+\mathrm{H})^{+}\right)$, while the other at $\mathrm{m} / \mathrm{z} 1013.6$ was $\mathrm{m} / \mathrm{z} 18$ higher than $(\mathrm{Mass}+\mathrm{H})^{+}$, corresponding to the protonated molecular ion $(\mathrm{M}+18+\mathrm{H})$ + (Figure 4). This ion peak at $\mathrm{m} / \mathrm{z} 1013.6$ indicated that parent MCLR ( $\mathrm{m} / \mathrm{z}$ 995.6) was hydrolyzed into a linearized form of MC-LR as intermediate product, with one hydrogen $(\mathrm{H})$ and one hydroxyl $(\mathrm{OH})$ added onto some group of the residue at each end of linearized MC-LR molecular, respectively, after ring-opening.

Furthermore, MS spectrum profile also revealed another predominant peak at $\mathrm{m} / \mathrm{z} 862.5$ observed as the second-most intensive peak only after $(\mathrm{M}+18+\mathrm{H})^{+}$(Figure 4$)$. This peak was $\mathrm{m} / \mathrm{z} 151$ lower than that of $(\mathrm{M}+18+\mathrm{H})^{+}$, and corresponded to a characteristic loss of terminal phenylethylmethoxy group ( $\mathrm{PhCH} 2 \mathrm{CHOCH} 3)$ and amino group (NH2) from the Adda residue of linearized MC-LR (Figure 4). This conversion is a common loss fragment due to the radical fragmentation rearrangement associated with electron delocalization from the 4, 6-conjugated diene of Adda residue following linearization

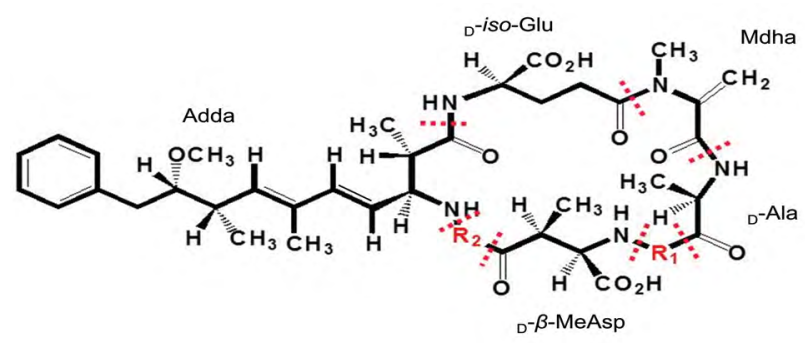

Figure 1: General chemical structure of MCs with a pair of variable amino acids at sites $R_{1}$ and $R_{2}$ ( - -Ala: ${ }_{0}$-Alanine; $-\beta$-MeAsp: ${ }_{D}$-erythro- $\beta$-methylaspartic acid; Adda: (2S, 3S, 8S, 9S)-3-amino-9-methoxy-2,6,8-trimethyl10-phenyldeca-4,6-dienoic acid; ${ }^{-i s o-G l u: ~}{ }^{-i s o-G l u t a m i c ~ a c i d ; ~ M d h a: ~}$ $\mathrm{N}$-methyl-dehydroalanine). 
Citation: Li J, Wang R, Li J (2018) Elucidating the Regulatory Functions of MlrA Originated from Novosphingobium sp. THN1 in Microcystin-LR Degradation. J Environ Anal Toxicol 8: 556. doi: 10.4172/2161-0525.1000556

$[8,17,18]$. The presence of this ion $(\mathrm{m} / \mathrm{z} 862.5)$ is thus an indicative of the linearized product including Adda residue with $\mathrm{N}$-terminal at one end,

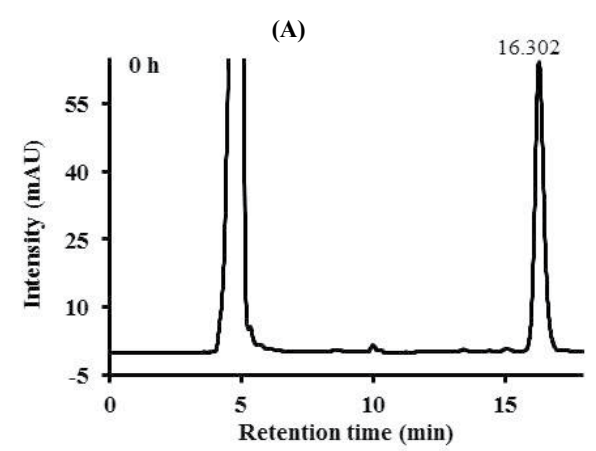

(B)

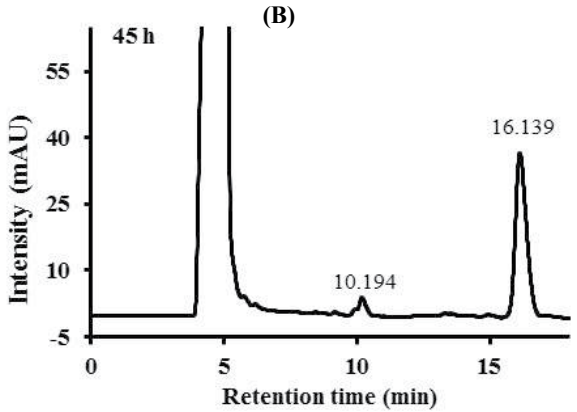

(C)

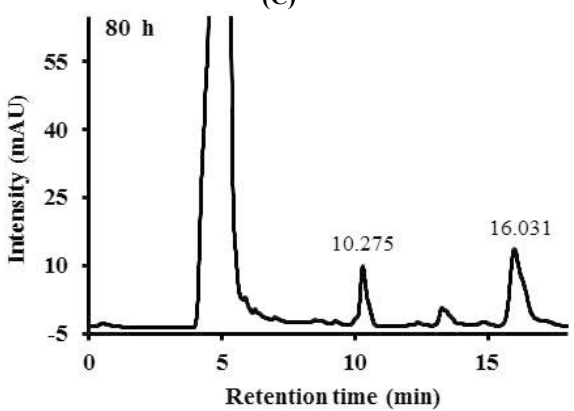

Figure 2: HPLC profile for MC-LR degradation by recombinant MlrA in CE extract at (A) 0 , (B) 45 and (C) $80 \mathrm{~h}$ of test period. Parent MC-LR was detected at the retention time of 16.1 16.3 min. Linearized MC-LR as primary degradation product was detected at the retention time of around $10.0 \mathrm{~min}$

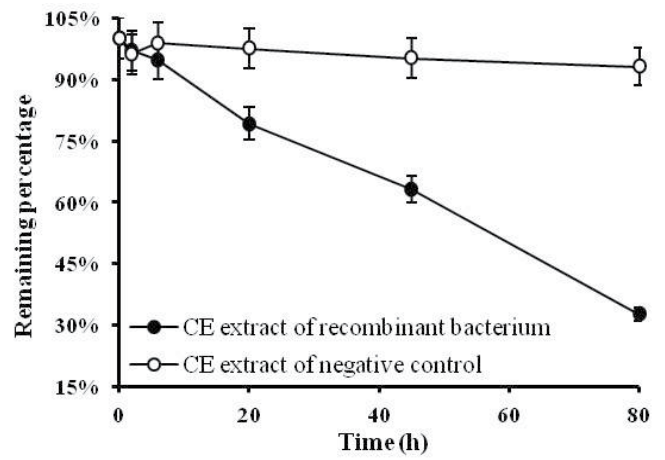

Figure 3: MC-LR degradation kinetics by recombinant MIrA in CE extract. Bars represent the standard errors of the means for triplicates.

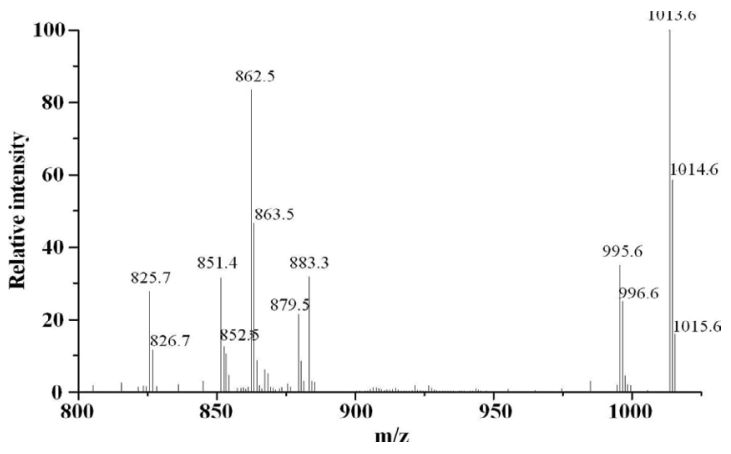

$\mathrm{m} / \mathrm{z} \quad$ MS precursor and product ions

$995.6 \quad[\text { Mass }+\mathrm{H}]^{+}$

$1013.6 \quad[\text { Mass }+\mathrm{H}+\mathrm{H}+\mathrm{OH}]^{+}$

$862.5 \quad\left[\mathrm{Mass}+\mathrm{H}+\mathrm{H}+\mathrm{OH}-\mathrm{C}_{6} \mathrm{H}_{5} \mathrm{CH}_{2} \mathrm{CHOCH}_{3}-\mathrm{NH}_{2}\right]^{+}$

The $\mathrm{H}$ and $\mathrm{OH}$ added after Adda-Arg bond cleavage are highlighted in bold.

Figure 4: The fragmentation patterns of MS spectrum for MC-LR and its degradation products catalyzed by recombinant MlrA.

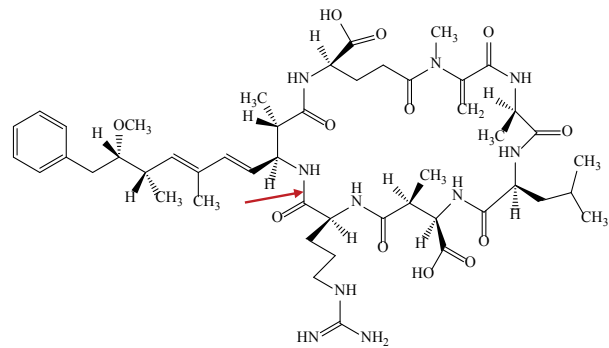

MC-LR (MW: 995.6)

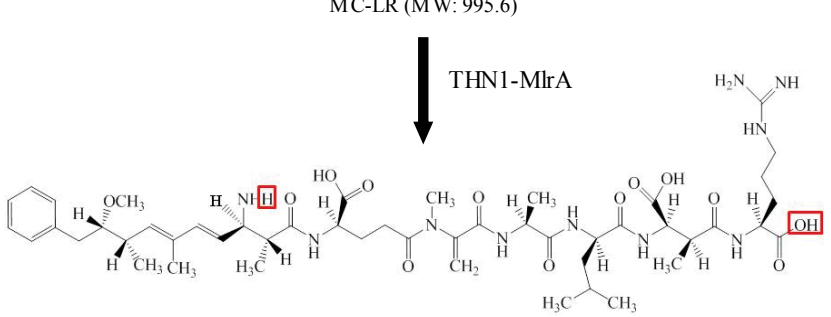

Linearized MC-LR (MW: 1013.6)

Figure 5: Catalytic scheme for MC-LR degradation by THN1-MlrA enzyme. The Adda-Arg bond cleavage is indicated by a red arrow. The $\mathrm{H}$ onto $\mathrm{NH}_{2}$ group of Adda residue and the $\mathrm{OH}$ onto carboxyl group of arginine following Adda-Arg bond cleavage are highlighted with red frames.

coinciding with previous report of Choi et al. [19]. Correspondingly, it can be inferred that the linearized product included a carboxylterminal arginine at the other end, and has a structure of NH2-AddaD-iso-Glu-Mdha-D-Ala-L-Leu-D-iso-MeAsp-L-Arg-OH. Hence, it was concluded that THN1-MlrA can hydrolyze cyclic MC-LR into a linearized product, by catalyzing the cleavage of Adda-Arg bond in MC-LR (Figure 5).

\section{Discussion}

Biodegradation is the primary pathway for MCs elimination from aquatic ecosystems. It is confirmed that MCs can be favorably degraded by a variety of $m l r A$-harboring bacteria indigenous to diverse habitats [6]. The $m l r A$ gene homolog conserves an extremely rare nucleotide 
Citation: Li J, Wang R, Li J (2018) Elucidating the Regulatory Functions of MlrA Originated from Novosphingobium sp. THN1 in Microcystin-LR Degradation. J Environ Anal Toxicol 8: 556. doi: 10.4172/2161-0525.1000556

Page 5 of 6

sequence, and encodes a highly specific protease (MlrA) with target substrate range limited to MCs [20,21]. THN1 strain, the first MCdegrader belonging to Novosphingobium genus, is a novel bacterium able to degrade MC-LR in virtue of its $m$ lrA gene expression [11], but the catalytic function of THN1-mlrA gene in MC-LR degradation was still unidentified. Noteworthy, former observations for other degraders cannot be directly applied to THN1 strain due to potential difference in amino acid sequences and structures of protease encoded by $m l r A$ homologs from different genera of bacteria, despite their genetic homology.

Here, we successfully cloned and expressed THN1-mlrA gene in heterologous host. Results verified that recombinant MlrA can be directly used to degrade MC-LR, without any necessity for predenaturing, purification and refolding as performed in Dziga et al. [21]. This implied that the recombinant MlrA might be expressed in an active form but not deposited as insoluble inclusion bodies in heterologous host here, exhibiting a less- costly and convenient application potential. Based on MS spectrum profile, it was clarified that THN1-MlrA can hydrolyze cyclic MC-LR into linearized MCLR as primary intermediate product (Figure 5). Furthermore, the ion peak interpreting the characteristic loss of $\mathrm{PhCH}_{2} \mathrm{CHOCH}_{3}$ and $\mathrm{NH}_{2}$ from Adda provided the evidence that the linearized product had an $\mathrm{N}$-terminal Adda and thus the evidence that the hydrolytic cleavage of MC-LR occurred at Adda-Arg bond. Consequently, MS spectrum verified that MC-LR degradation by THN1 strain involved Adda-Arg bond cleavage under hydrolytic effect of MlrA enzyme, with concurrent addition of a $\mathrm{H}$ onto amino group of Adda residue and a $\mathrm{OH}$ onto carboxyl group of arginine (site R2) (Figure 5). The linearization process in MC-LR degradation by THN1-mlrA was congruent with the cases for Sphigomonas sp. ACM-3962 and Sphingopyxis sp. USTB-05 strains $[8,9,22]$.

Importantly, formation of such linearized intermediate through Adda-Arg bond cleavage qualified as a detoxification process for MCLR, leading to a 160 -fold reduction in toxicity compared with parent MC-LR. Until recently, numerous studies have confirmed that such linearized intermediate is much less toxic or even non-toxic at least at environmentally-relevant concentrations $[8,9,21,23]$. This substantial detoxification caused by linearization was presumably ascribed to the alteration in the interaction between MC-LR and PPs, especially the changes in affinity to the active site of PPs $[8,9]$. Also, in contrast to cyclic form, linearized MC-LR is much less stable and more prone to be further rapidly degraded into smaller peptides fragments and/or amino acids by peptidases [8-10]. From these views, THN1-MlrA is of particular importance in ensuring ecosystem safety and public health, as it could open highly-stable cyclic structure of MC-LR and cause MCLR decontamination in natural waters.

This study for the first time revealed the catalytic hydrolysis mechanism of MlrA originated from Novosphingobium genus in MCLR biodegradation, and ensured that THN1-MlrA enzyme conserved its original catalytic function of ring-opening and detoxification for MC-LR [9]. As the most toxic and abundant analog of MCs, MC-LR poses extremely high risk to ecosystem safety and public health [7]. To elucidate MC-LR biodegradation mechanisms is crucial to better assess its fate and the risk of its degradation products in natural habitats. Unlike ACM-3962 and USTB-05 strains, Novosphigobium sp. THN1 is native to Lake Taihu, hence this study expanded the knowledge on the function of MlrA homologs originated from various natural habitats, and was meaningful for acquiring the fate, bio-elimination mechanisms and risk decrease of MC-LR in Lake Taihu, where MC-
LR was frequently detected during bloom period over decades [24]. In future, more $m l r A$-harboring MC-degraders should be employed to clarify whether catalytic hydrolysis schemes of MlrA towards MC- LR are identical among a wide range of strains and maintain its function along phylogenetic evolution process.

\section{Acknowledgements}

This work was supported by the National Natural Science Foundation of China (No. 31300434) and the Research Fund for the Doctoral Program of Higher Education of China (No. 20130008120026).

\section{References}

1. Paerl HW, Otten TG (2013) Blooms bite the hand that feeds them. Science 342: 433-434.

2. Isobe T, Okuhata H, Miyasaka H, Jeon BS, Park HD (2014) Detoxification of microcystin-LR in water by Portulaca oleracea cv. Journal of Bioscience and Bioengineering 117: 330-332.

3. Lawton LA, Robertson PKJ (1999) Physico-chmical treatment methods for the removal of microcystins (cyanobacterial hepatotoxins) from potable waters. Chemical Society Reviews 28: 217-224.

4. Okano K, Maseda H, Sugita K, Saito T, Utsumi M, et al. (2006) Biochemical characteristics of microcystin LR degradation by typical protease. Japanese Journal of Water Treatment Biology 42: 27-35.

5. Li J, Li J, Shi G, Mei Z, Wang R, et al. (2016) Discerning biodegradation and adsorption of microcystin-LR in a shallow semi-enclosed bay and bacterial community shifts in response to associated process. Ecotoxicology and Environmental Safety 132: 123-131.

6. Li J, Li R, Li J (2017) Current research scenario for microcystins biodegradation-a review on fundamental knowledge, application prospects and challenges. Science of the Total Environment 595: 615-632.

7. Merel S, Walker D, Chicana R, Snyder S, Baurès E, et al. (2013) State of knowledge and concerns on cyanobacterial blooms and cyanotoxins Environment International 59: 303-307.

8. Bourne DG, Jones GJ, Blakeley RL, Jones A, Negri AP, et al. (1996) Enzymatic pathway for the bacterial degradation of the cyanobacterial cyclic peptide toxin microcystin LR. Applied and Environmental Microbiology 62: 4086-4094.

9. Bourne DG, Riddles P, Jones GJ, Smith W, Blakeley RL (2001) Characterisation of a gene cluster involved in bacterial degradation of the cyanobacterial toxin microcystin LR. Environmental Toxicology 16: 523-534.

10. Cousins IT, Bealing DJ, James HA, Sutton A (1996) Biodegradation of microcystin-LR by indigenous mixed bacterial populations. Water Research 30: 481-485.

11. Jiang $Y$, Shao J, Wu X, Xu Y, Li R (2011) Active and silent members in the $\mathrm{mlr}$ gene cluster of a microcystin degrading bacterium isolated from lake Taihu, China. FEMS Microbiology Letters 322: 108-114.

12. Li J, Peng L, Li J, Qiao Y (2014) Divergent responses of functional gene expression to various nutrient conditions during microcystin-LR biodegradation by Novosphingobium sp. THN1 strain. Bioresource Technology 156: 335-341.

13. Wang R, Li J, Jiang Y, Lv Z, Li R, et al. (2017) Heterologous expression of mIrA gene originated from Novosphingobiumsp.THN1 to degrade microcystin$\mathrm{RR}$ and identify the first step involved in degradation pathway. Chemosphere 184: $159-167$.

14. Cheng Y, Yang C, Liu W (2005) Cloning and expression of Thermobifida xylanase gene in the methylotrophic yeast Pichia pastoris. Enzyme and Microbial Technology 37: 541-546.

15. Nakamura T, Ichinose $H$, Wariishi $H$ (2010) Cloning and heterologous expression of two aryl-aldehyde dehydrogenases from the white-rot basidiomycete Phanerochaete chrysosporium. Biochemical and Biophysical Research Communications 394: 470-475.

16. Lu L, Wang T, Xu T, Wang J, Wang C, et al. (2013) Cloning and expression of thermo-alkali-stable laccase of Bacillus licheniformis in Pichia pastoris and its characterization. Bioresource Technology 134: 81-86.

17. Li J, Shimizu K, Zhou Y, Utsumi M, Sakharkar MK, et al. (2011) Biodegradation of microcystins by bacterial communities co-existing with flagellate Monas guttula and concurrent succession of the community structures. Journal of 
Citation: Li J, Wang R, Li J (2018) Elucidating the Regulatory Functions of MlrA Originated from Novosphingobium sp. THN1 in Microcystin-LR Degradation. J Environ Anal Toxicol 8: 556. doi: 10.4172/2161-0525.1000556

Page 6 of 6

Water Supply: Research \& Technology-Aqua 60: 352-363.

18. Namikoshi M, Rinehart KL, Sakai R, Stotts RR, Dahlem AM, et al. (1992) Identification of 12 hepatotoxins from a Homer Lake bloom of the cyanobacteria Microcystis aeruginosa, Microcystis viridis, and Microcystis wesenbergii: nine new microcystins. The Journal of Organic Chemistry 57: 866-872.

19. Choi B, Namikoshi M, Sun F, Rinehart KL, Carmichael WW, et al. (1993) Isolation of linearized peptides related to the hepatotoxins nodularin and microcystins. Tetrahedron Letters 34: 7881-7884.

20. Saito T, Okano K, Park HD, Itayama T, Inamori Y, et al. (2003) Detection and sequencing of the microcystin LR-degrading gene, $m / r A$, from new bacteria isolated from Japanese. FEMS Microbiology Letters 229: 271-276.

21. Dziga D, Wladyka B, Zielińska G, Meriluoto J, Wasylewski M (2012)
Heterologous expression and characterisation of microcystinase. Toxicon 59: 578-586.

22. Yan H, Wang H, Wang J, Yin C, Ma S, et al. (2012) Cloning and expression of the first gene for biodegrading microcystin LR by Sphingopyxis sp. USTB-05. Journal of Environmental Science 24: 1816-1822.

23. Dziga D, Lisznianska M, Wladyka B (2014) Bioreactor study employing bacteria with enhanced activity toward cyanobvacterial toxins microcystins. Toxins 6 : 2379-2392.

24. Ye R, Shan K, Gao H, Zhang R, Xiong W, et al. (2014) Spatio-temporal distribution patterns in environmental factors, chlorophyll-a and microcystins in a large shallow lake, Lake Taihu, China. Internatiobnal Journal of Environmental Research and Public Health 11: 5155-5169. 